www.volsu.ru

DOI: http://doi.org/10.15688/nav.jvolsu.2018.1.4

UDC 902(653):(093)

LBC 63.444-429

\title{
PAPAGIYA OF THE CONSTANTINE VII PORPHYROGENITUS'TREATISE DE ADMINISTRANDO IMPERIO IN THE LIGHT OF WRITTEN AND ARCHAEOLOGICAL SOURCES
}

\author{
Inga A. Druzhinina \\ Institute of Archaeology of Russian Academy of Sciences, Moscow, Russian Federation
}

\begin{abstract}
Constantine VII Porphyrogenitus' treatise De Administrando Imperio contains unique information on the country of Papagiya located in the Northwest Caucasus between Zikhiya and Kasakhiya. The present paper deals with the issues of Papagiya localization in the Trans-Kuban region and the ethnocultural features of the Papags on the basis of the complex analysis of archaeological and written sources.

We make a conclusion that the territory of Papagiya corresponds to the area of cremation burials of the end of the $7^{\text {th }}-9^{\text {th }} \mathrm{cc}$. Besides, we assume the multi-ethnic character of the country's population, which includes the representatives of cremation rites, the prabolgar tribes and local settled tribes of the foothills. The general reconstruction of history of Papagiya is proposed. At the time of the Khazar Khaganate, Papagiya played the leading role on a left bank of Kuban, but in the first half of the $10^{\text {th }}$ century under the pressure of nomads and in the conditions of a general crisis of Khazaria, Papagiya lost its status. The name of this country was no longer mentioned in written sources, and its population accepted the name of the Kasogs.

Key words: Constantine VII Porphyrogenitus, treatise De Administrando Imperio, Papagiya, Northwest Caucasus, Byzantium, Khazar Khaganate, Zikhs, Kasogs, archaeological sources, cremation burials.

Citation. Druzhinina I.A., 2018. Papagiya of the Constantine VII Porphyrogenitus' Treatise De Administrando Imperio in the Light of Written and Archaeological Sources. The Lower Volga Archaeological Bulletin, vol. 17, no. 1, pp. 76-89. (in Russian).
\end{abstract}

УДК 902(653):(093)

ББК 63.444-429

\section{ИСТОРИЧЕСКАЯ ОБЛАСТЬ ПАПАГИЯ \\ ТРАКТАТА КОНСТАНТИНА УІІ БАГРЯНОРОДНОГО «ОБ УПРАВЛЕНИИ ИМПЕРИЕЙ» \\ В СВЕТЕ ПИСЬМЕННЫХ И АРХЕОЛОГИЧЕСКИХ ИСТОЧНИКОВ}

\author{
Инга Александровна Дружинина \\ Институт археологии РАН, г. Москва, Российская Федерация
}

\footnotetext{
Аннотация. Сочинение Константина VII Багрянородного «Об управлении империей» содержит уникальную информацию о «стране Папагии», расположенной на Северо-Западном Кавказе, между Зихией и Касахи$\infty$ ей. В публикации на основе комплексного анализа археологических и письменных источников рассматриваются вопросы локализации Папагии на карте Закубанья и этнокультурной атрибуции папагов.

Сделан вывод о соответствии территории Папагии ареалу грунтовых кремационных погребений конца VII - IX в., а также о полиэтничном составе ее населения, включавшем носителей обряда кремаций, представителей праболгарских племен и местных оседлых племен предгорий. Предложена общая реконструкция истории Папагии. Во времена Хазарского каганата Папагия играла лидирующую роль на левобережье Кубани, но в первой половине Х столетия под ударом кочевников и в условиях общего кризиса Хазарии Папагия 章 потеряла свои позиции, название этой «страны» больше не встречается на страницах письменных источни(?) ков, а ее население приняло имя вышедших на авансцену истории касогов.
} 
Ключевые слова: Константин VII Багрянородный, трактат «Об управлении империей», Папагия, Северо-Западный Кавказ, Византия, Хазарский каганат, зихи, касоги, археологические источники, кремационные погребения.

Цитирование. Дружинина И. А., 2018. Историческая область Папагия трактата Константина VII Багрянородного «Об управлении империей» в свете письменных и археологических источников // Нижневолжский археологический вестник. Т. 17, № 1. С. 76-89.

Два с половиной века истории изучения Папагии показали, что сведений единственного источника - сочинения Константина Багрянородного «Об управлении империей» - для уточнения локализации этой загадочной «страны» на карте Закубанья и определения этнической природы ее населения не достаточно [Дружинина, 2017 , с. 42]. Современные научные представления о средневековой истории и археологии Северо-Западного Кавказа позволяют подойти к решению данных вопросов с новых позиций.

Обратимся к сочинению Константина Багрянородного: «За Таматархой, в 18 или 20 милях, есть река по названию Укрух, разделяющая Зихию и Таматарху, а от Укруха до реки Никопсис, на которой находится крепость, одноименная реке, простирается страна Зихия. Ее протяженность 300 миль. Выше Зихии лежит страна, именуемая Папагия, выше страны Папагии - страна по названию Касахия, выше Касахии находятся Кавказские горы, а выше этих гор - страна Алания» [Константин Багрянородный, 1991, с. 171, 175]. В другом месте текста перечислены нефтяные источники Зихии и расположенные рядом с ними населенные пункты, среди которых названы: «место Паги, находящееся в районе Папагии», место «Папаги, близ которого находится деревня, именуемая Сапакси». При этом указано, что «отстоят эти места от моря на один день пути без смены коня» [Константин Багрянородный, 1991, с. 272-273].

Итак, Папагия упоминается в источнике трижды: в названии главы 42, непосредственно в тексте этой главы и на последних листах заключительной главы 53. Эти сведения в известной степени противоречивы.

В первых двух случаях Папагия показана как самостоятельная область или «страна». В названии и тексте главы 42 она поставлена в один ряд с Зихией, Касахией, Аланией и Авасгией. Однако в 53 главе указывается, что в населенных пунктах Папагии прожива- ют зихи, и сами эти поселения расположены в Зихии. Сведения 53 главы дали основание исследователям рассматривать Папагию как часть Зихии [Гадло, 1979, с. 194; 1994, с. 25; Каминский, 1993, с. 75], при этом авторы никак не комментировали независимое положение Папагии, следующее из текста главы 42.

Противоречие сведений трактата может найти объяснение в истории создания самого источника. В рецензии на Второй том: комментарии к тексту Константина Багрянородного «Об управлении империей» А.П. Каждан с ссылкой на Р. Дженкинза указывал, что информация, содержащаяся в главах 14-42, не выходит за пределы IX в., и предназначалась для трактата «О народах», который, по замыслу Константина, должен был описывать события далекого прошлого, главным образом - происхождение народов [Каждан, 1967, с. 336]. Однако общая идея труда изменилась: вместо книги по истории, к 14-летию сына Романа Константин подготовил практическое руководство по внешней и внутренней политике, при этом в текст были внесены актуальные к середине X столетия сведения [Каждан, 1967, с. 336; Литаврин, 1991, с. 24]. В этом свете, по-видимому, должны рассматриваться и заключительные страницы главы 53 с перечислением нефтяных источников на территории Зихии, добавленные к пересказам легендарных событий из жизни херсонитов I в. до н.э. - IV в. н.э. [Литаврин, 1991, c. 23]. Следовательно, сообщения о Папагии в главах 42 и 53 содержат два пласта информации, соответствующих различнылм хронологическим и этнополитическим срезам истории Северо-Западного Кавказа.

Трактат «Об управлении империей» позволяет сделать следующие предварительные выводы:

1. На Северо-Западном Кавказе в «хазаро-византийское время» существовала «страна Папагия». К середине X в. она занимала определенную часть Закубанья, на ее терри- 
тории располагались ближайшие от побережья нефтяные источники, однако границы этой земли точно не определены. При этом в источнике Папагия четко позиционирована как область, отдельная не только от причерноморской Зихии, но и от закубанской Касахии.

2. Выделяются два периода в истории Папагии. Первый условно можно назвать «Папагия - страна», и характеризуется он известной политической самостоятельностью этой исторической области. Следует подчеркнуть, что даже в тех границах, которые аморфно намечены Константином Багрянородным для середины X в., Папагия занимала один из наиболее привлекательных районов Закубанья - равнинную территорию вдоль главной водной артерии региона, с нефтяными источниками, столь значимыми для Византии. Само по себе это обстоятельство указывает на сильные, если не ключевые позиции Папагии на левобережье Кубани в определенный момент ее истории. Представляется допустимым, что часть морского побережья к северу от Геленджика также относилась к Папагии, так как согласно Анонимному трактату Periplus Ponti Euxini (cep. VI cep. IX в.) этот район не был занят зихами - они проживали к югу от Пагр (Эптала), то есть в районе современного Геленджика [Латышев, 1890, с. 278-279; Виноградов, 2009, с. 188].

Второй период в истории Папагии связан с продвижением зихов с побережья, где их застал Анонимный трактат, на северные склоны Кавказского хребта (к северу от Геленджика до старого русла Кубани - p. Укрух), и может быть обозначен как «Папагия - часть Зихии». Собственно, именно в этом состоянии зафиксировал Папагию византийский источник в середине Х в. О каких-либо точных хронологических границах второго периода говорить довольно сложно, при этом позднее упоминания в источнике, то есть после середины $\mathrm{X}$ в., Папагия не встречается на страницах средневековых текстов.

Важно подчеркнуть: исторические условия для продвижения зихов в низовья Кубани сложились в годы «системного кризиса» Хазарского каганата, который «ознаменовался давлением со стороны Древней Руси, Хорезма, тюрок-огузов, Ширвана» [Калинина, 2015, c. 120]. Археологические материалы степного Закубанья «подтверждают наличие значительного адыгского населения только с Х в. - времени упадка и разгрома Хазарского каганата. Этим же периодом датируется верхняя граница памятников как салтовской культуры в целом, так и ее кубанского варианта» [Тарабанов, 1996, с. 99-100]. А это может означать, что Папагия до того, как была занята зихами, непосредственно контролировалась хазарскими властями.

Письменные источники не сохранили названия племен, населявших Закубанье в эпоху раннего средневековья. Свои этнические имена обитатели края обретают на страницах трудов арабских, византийских и древнерусских авторов только с Х в. Ключевая роль в изучении этнической истории региона этого времени принадлежит археологии. И хотя полная этнокультурная картина по результатам археологических исследований сегодня воссоздана быть не может (так, например, чрезвычайно слабо изучены памятники VIII-X вв. предгорий Закубанья), тем не менее, уже можно констатировать ряд отправных положений.

1. На равнинной территории Западного Закубанья памятники, которые можно было бы определенно связать со средневековыми предками адыгов, известны только с конца Х в. [Тарабанов, 1983, с. 93-94; Пьянков, 1989, с. 111 и др.]. В нижнем течении Псекупса появляются ингумации с западной ориентировкой, угольной подсыпкой, полным отсутствием костей животных - признаками, характерными для погребального обряда позднесредневековых адыгов [Тарабанов, 1996, с. 99]. Антропологический материал этих погребений (могильник Казазово II) находит ближайшие параллели в «причерноморской группе адыгских курганов» [Герасимова, Тихонов, 2003, с. 288-289; Дружинина, 2016, с. 213] ${ }^{1}$.

2. На рубеже VI-VII вв. в степной зоне Закубанья появляется новое население, с которым связывают грунтовые погребения в длинных узких ямах с преобладающей северо-восточной ориентировкой. Эти памятники увязываются с праболгарскими племенами ${ }^{2}$ [Тарабанов, 1993, с. 39; 1996, с. 98; Носкова, 2002, с. 178].

3. С конца VII в. побережье в районе Анапы - Геленджика и степное Закубанье вплоть до устья р. Псекупс занимают носители обряда грунтовых кремационных погребений [Успенский, 2015]. Вопрос об этнокультурной атрибуции этого населения остается 
открытым (обзор версий см.: [Пьянков, Тарабанов, 2008, с. 279-280]). При этом по способу захоронения кремированных останков (безурновые, урновые, в каменных ящиках) выделяются три локально-территориальные группы могильников [Успенский, 2013, с. 9192], что может указывать и на этническую неоднородность носителей нового обряда, и на восприятие его местными племенами.

4. C VI в. следы местного «постмеотосарматского» населения в степном Закубанье практически не прослеживаются. Это население «либо исчезает, либо подчиняется новым пришельцам, полностью воспринимая не только их хозяйственный уклад, но и весь комплекс культурно-идеологических воззрений» [Носкова, 2002, с. 178-179]. В предгорьях с местными племенами связывают грунтовые ингумации IV-IX вв., для которых характерно положение погребенного вытянуто на спине, наличие инвентаря и заупокойной пищи [Джигунова, 2000 , с. $10 ; 2007$, с. 154]. По-видимому, смешением местных племен и носителей обряда кремаций объясняется формирование в устье Псекупса локального варианта кремационного погребального обряда - урновых трупосожжений. Тем более что исследователи обращают внимание на своеобразие керамики из кремационных погребений, которая на фоне остального инвентаря, имеющего прямые аналогии в древностях салтово-маяцкой культуры, «локальна и частью явно связана с местными традициями» [Гавритухин, Пьянков, 2003, с. 198; Джигунова, 2007, с. 155]. В данной связи повсеместное распространение - в Северо-Восточном Причерноморье, в степях и предгорьях Западного Закубанья - именно этого варианта обряда уже на следующем этапе, в XIXIII вв., может указывать на возвышение роли местных племен в регионе в постхазарский «касожский» период.

Важно подчеркнуть, что ареал грунтовых кремаций (побережье от Анапы до Геленджика и степное Закубанье до нижнего течения p. Псекупс) в конце VII - IX в. представлял собой регион, отличный по своим этнокультурным характеристикам от побережья Черного моря между Геленджиком и р. Нечепсухо, населенного зихами, где были распространены грунтовые ингумации с различной ориентировкой в простых ямах и каменных ящиках [Ан- фимов, 1980; Пьянков, 1998, с. 48-52; Гавритухин, Пьянков, 2003, с. 194], от Тамани, где в эпоху средневековья полиэтничное население хоронило умерших по обряду ингумации в простых грунтовых ямах и каменных ящиках [Чхаидзе, 2006а, с. 196-197; 2006б, с. 53-86], от района степного Прикубанья, где преобладало праболгаро-аланское население, хоронившее своих соплеменников в грунтовых ямах с преобладающей северо-восточной ориентировкой и в катакомбах [Каминский, 1984; 1987], от района Восточного Закубанья, который рассматривается как периферия аланской культуры [Каминский, 1989 , с. $97 ; 1993$, с. 83], а также от предгорий Западного Закубанья, где сохранились традиции ингумационных погребений [Джигунова, 2000, с. 10; 2007, с. 154] и где кремации этого времени не распространены.

Можно ли локализовать исторические области Северо-Западного Кавказа, упомянутые в трактате «Об управлении империей», в границах ареала грунтовых кремаций? В историографии сформировались четыре варианта такой локализации ${ }^{3}$.

Вариант 1. Ареал грунтовых кремаций охватывает территорию сразу трех «стран» (полностью или частично - ?). Предложивший этот вариант П.С. Успенский соотносит кремации из степного Закубанья с территорией Папагии и Касахии, а причерноморскую группу трупосожжений - с территорией расселения зихов. Распространение кремационного обряда в регионе исследователь связывает не с появлением новых племен, а с «иным мировоззренческим импульсом в среде местного населения, выразившемся в восприятии новой погребальной практики» [Успенский, 2015, с. 25-26]. Что это за «импульс», П.С. Успенский не поясняет.

Вариант 2. В зоне кремационных погребений располагаются и Папагия, и Касахия, носителями обряда кремаций является население обеих земель. В этом случае восточная группа памятников в районе Краснодарского водохранилища может быть соотнесена с территорией Касахии. На территории Папагии локализуется вторая группа могильников, а также самая западная, расположенная между Анапой и Геленджиком. Этот вариант отчасти согласуется с локализацией Папагии и Касахии, предложенной В.Н. Каминским [Каминский, 1993]. 
Вариант 3. Носителями обряда кремаций являются исключительно касахи - касоги [Пьянков, 2001, с. 204], при этом остается не понятным, какие археологические памятники можно соотнести с населением Папагии, расположенной, согласно мнению самого же А.В. Пьянкова, в самом центре зоны распространения кремационных погребений.

Вариант 4. Ареал племен грунтовых кремаций соответствует территории Папагии. Касахи занимают предгорья Западного Закубанья и этнически отличны от населения степной полосы кубанского левобережья. Данный вариант согласуется со взглядами В.Н. Каминского, связывавшего с касахами грунтовые ингумации с западной ориентировкой могильника Казазово II [Каминский, 1993, с. 75], а также В.А. Тарабанова, полагавшего, что в VIII-X вв. поселения и могильники болгар и племен обряда кремаций «проходят цепью от левобережья Средней Кубани, через предгорья (могильник села Молдованское Крымского района) идут на побережье (Борисовский могильник у Геленджика, могильник Дюрсо), то есть как бы закрывают выход с гор воинственных адыгских племен (касогов), подчинение которых каганату в VIII-X вв. было, повидимому, чисто номинальным и выражалось скорее всего в выплате дани хазарам» [Тарабанов, 1993, с. $39-40 ; 1996$, с. 99].

Как убедительно показал А.В. Пьянков, обряд кремаций не имеет местных корней на Северо-Западном Кавказе и связан с инфильтрацией в местную среду нового населения [Пьянков, 2001, с. 204-205]. В качестве возможных причин появления племен обряда кремаций в Кубано-Черноморском регионе исследователи называют: стремление Хазарии обеспечивать стабильность на западном участке «великого шелкового пути», в связи с чем на границы каганата были переселены древние венгры для несения «пограничной службы, возложенной хазарской администрацией» [Тарабанов, 1993, с. 39; 1994, с. 58]; перекочевку групп тюркского населения в пределы Хазарского каганата в результате возникшей «в середине VIII века в связи с завоеваниями арабов и уйгуров в Южной Сибири напряженной военно-политической обстановки» [Дмитриев, 1978, c. 49]; укрепление западных границ каганата [Гадло, 1994, с. 25; Кочкаров, 2008, с. 90]. Все эти версии подчеркивают прямую связь племен обряда кремаций с Хазарией.

Интересно и то, что динамика и территория распространения данного типа памятников корреспондируют со сведениями трактата Константина Багрянородного о Папагии. Отмечается резкое сокращение числа могильников с трупосожжениями $\mathrm{X}$ в., они исчезают с территории Северо-Восточного Причерноморья и известны лишь в восточной части ареала [Пьянков, 2001, с. 205; Успенский, 2015, с. 13]. Именно в это время Папагия переживает кризис: к середине X в. эту область занимают зихи ${ }^{4}$.

А.В. Пьянков связывает сокращение ареала кремаций с «аланскими походами, о которых сообщают Масуди и Багрянородный и которые привели к ослаблению и сокращению численности касогов» [Пьянков, 2001, с. 205]. С этой версией во многом согласуются выводы О.Б. Бубенка о захвате аланами поселений касогов и продвижении аланской границы к черноморскому побережью после падения Хазарии в 965 г. [Бубенок, 2015, с. 35]. Со своей стороны отметим, что направление, в котором происходило сокращение ареала кремаций в начале $\mathrm{X}$ в., связанное, прежде всего, с исчезновением самой крупной группы памятников, локализованной в районе Анапы - Геленджика, указывает на то, что одной из причин исхода с побережья носителей обряда кремаций стало продвижение на эту территорию зихов. Данный вывод согласуется с сообщением «Кембриджского анонима» о войне хазар с народом Зибус, в котором П.К. Коковцов видел зихов [Коковцов, 1932, с. 123, прим. 23]. Благоприятные условия для расширения северной границы зихов могли возникнуть в результате нападения в конце IX в. на прибрежные районы Северо-Западного Кавказа кочевников - печенегов или венгров. Последствием этих событий стал разгром Фанагории, в слоях которой выявлен мощный слой пожарища второй половины IX в. [Чхаидзе, 2012a, с. 271-281]. Этот набег, по-видимому, затронул и носителей обряда кремаций, проживавших на побережье.

Итак, строгая ландшафтная зональность кубано-черноморских кремаций конца VII - IX в., единовременное резкое сокращение их числа и изменение их ареала к началу X в. позволяют признать вариант о соответствии территории Папагии области распространения этой группы памятников - наиболее логичным (рис. 1$)^{5}$. 
Относительно «касожской гипотезы» происхождения кубано-черноморских кремаций коротко остановимся на ряде моментов, важных для раскрытия нашей темы. В отличие от Касахии, с жителями которой исследователи увязывают кремационные могильники конца VII - XIII в. [Пьянков, 2000; 2001; 2004; Схатум, 2002; Армарчук, 2003; Бубенок, 2014], историю Папагии a priori ограничивают рамками первой половины $X$ в. Однако обе эти исторические области впервые появляются на страницах письменных источников почти одновременно: сообщение ал-Масуди о кашаках (касахах) относится к 30-м гг. Х в., в середине этого же столетия Папагию упоминает Константин Багрянородный.

Отождествление касогов с носителями обряда трупосожжения восходит к сообщению второй половины 30-х гг. Х в. ал-Масуди о кешаках (кашаках), которые «живут по соседству с аланами между Кабхом и Румским морем» и «исповедуют религию маджус» [Минорский, 1963, c. 206]. В.Ф. Минорский указывал, что «мусульманские авторы применяют название маджус к древним русам и норманнам из-за их обычая сжигать мертвых, описанного у Ибн Фадлана. Это «сжигание на корабле» могло быть неправильно понято, как «огнепоклонничество» [Минорский, 1963, с. 206, прим. 81]. Именно это наблюдение В.Ф. Минорского позволило А.В. Пьянкову соотнести носителей кремационного обряда СевероЗападного Кавказа с кашаками ал-Масуди.

Однако словом ал-маджус средневековые восточные авторы называют и просто язычников [Калинина, 2001, с. 199]. Во-вторых, как не раз отмечалось исследователями, «кашаки» ал-Масуди, так же как и «касоги» русских летописей - собирательное название для всех адыгских племен, воспринятое другими народами от восточных соседей адыгов - алан» [Лавров, 2009, с. 103; Алексеева, 1971, с. 180; Гадло, 1979, с. 194 и др.] ${ }^{6}$. Следовательно, в роли носителей обряда кремаций помимо кашаков - касогов, с еще большим основанием территориального соответствия, могут рассматриваться и жители Папагии.

В-третьих, из письма хазарского царя Иосифа к кордовскому вельможе Хасдаю ибнШафруту известно, что «все живущие в стране Каса», расположенной в непосредственной близости от алан, платят дань хазарам [Коковцов, 1932, с. 101]. По мнению П.К. Коковцова, под именем жителей «страны Каса» «следует разуметь соседний с аланами народ "Кашак" арабских географов, или Касогов русских летописей» [Коковцов, 1932, с. 105, примеч. 14]. Сведения письма хазарского царя Иосифа о выплате народом Каса дани хазарам получили неожиданную оценку А.В. Пьянкова: «судя по названию страны Каса, для хазар в VIIIIX вв. самым важным народом в Прикубанье были касоги, и, следовательно, они были доминирующим народом в регионе» [Пьянков, 2004 , с. 159]. Между тем исследователи многократно обращали внимание на значительное содержание предметов вооружения и конского снаряжения в кремационных погребениях [Кочкаров, 2006, с. 120], на военную профессиональную специализацию населения, оставившего эти памятники [Новичихин, 2014, c. 79-80], и высокую степень милитаризации их общества [Успенский, 2015, с. 21]. Представляется, что «доминирующей силой» являлось милитаризированное население, появившееся в регионе на рубеже VII-VIII вв. и занявшее наиболее благоприятные в стратегическом и хозяйственном отношении территории равнинного левобережья Кубани. По всей видимости, именно носители обряда кремаций - собирали дань со «всех, кто живет в стране Каса», а, следовательно, не относились к населению этой «страны». При этом Папагия претендует на политическое лидерство в регионе до начала $\mathrm{X}$ в. Соответствие ее хронологических (хазарское время) и географических (Закубанье) координат времени, динамике и территории распространения кремаций конца VII - начала X в. позволяет рассматривать носителей обряда трупосожжения как главный компонент в составе населения Папагии. Высокая степень милитаризации этого населения, управляемого элитарной прослойкой воинов-всадников, указывает на принадлежность их вождей военно-административному аппарату каганата.

В данной связи в новом свете предстает рассказ Никифора и Феофана о неудачной попытке убийства бежавшего в Фанагорию императора Юстиниана II Ринотмета (685-695; 705-711) «людьми хакана» Папацем и Валгицем [Феофан, 1980, с. 39/62, 40/63]. 
В научной литературе в контексте изучения сфер влияния Византии и Хазарии в Крыму и на Тамани эта история обсуждалась многократно (см.: [Чхаидзе, 2012а, с. 268269]). Фанагория, где в 698 г. была создана резиденция для императора, в которой тот пребывал около десяти лет, как и вся остальная часть Таманского полуострова, по всей видимости, находилась под двойным управлением Византии и Хазарии [Сорочан, 2007, с. 212, 214; Чхаидзе, 2012a, с. 266].

Валгиц у Феофана назван архонтом Боспора [Феофан, 1980, с. 62-63], у Никифора архонтом Скифского Боспора [Никифор, 1980, c. 163]. Установлено, что Валгиц - это не личное имя, а титул хазарского чиновника [Чхаидзе, 2005а, с. 170-171; Могаричев и др., 2007, c. 87-88]. Этот титул в несколько измененной форме Бул-ш-ци (Булшци - Булгиц - Балгиц Валгиц) встречается в «Отрывке из письма неизвестного хазарского еврея X в.» или «Кембриджском документе» [Чхаидзе, 2005a, c. 170-171]. По мнению ряда исследователей, в этом термине отразилось этническое название праболгар [Коковцов, 1932, с. 118-119; Артамонов, 1952, с. 44-45; Плетнева, 1981, с. 15].

Вопрос о праболгарах Прикубанья имеет собственную историографию, и здесь нет необходимости обращаться к его подробному освещению. Следует лишь отметить, что появление и заметное присутствие праболгар на территории Таманского полуострова археологические материалы фиксируют не ранее конца VII в. [Чхаидзе, 2005б, с. 358-359; 2007, c. $142 ; 20126$, с. 19], когда под давлением хазар праболгары выдвинулись из степей Прикубанья на запад - на Тамань и в Крым. Повидимому, эти же самые события вызвали этнические перестановки в Закубанье, где на рубеже VII-VIII вв. отмечается приток нового населения - носителей обряда кремаций.

И здесь особый интерес представляет второй фигурант истории с покушением на Юстиниана - упомянутый Феофаном Папац. Феофан сообщает, что Папац был «в Фанагории от его (кагана. - И. Д.) лица» ${ }^{7}$ [Феофан, 1980 , с. 62], что, по видимости, указывает на его тюркскую должность тудуна [Чичуров, 1980, с. 126, прим. 316]. Имя Папаца возводят от тюркского Babajïq или Babajuq [Minorsky, 1960, p. 131; Golden, 1980, p. 205].
Никифор имя этого исторического персонажа не упоминает, но говорит о нем, как об «архонте из единоплеменников, жившем при Юстиниане», а также как о «местном хазарине» [Никифор, 1980, с. 163]. При этом архонтом Никифор называет и самого кагана. И.С. Чичуров подчеркнул: «Никифор называет его (Папаца. - И. Д.), так же как и хазарского хагана, архонтом, хотя из “Хронографии" Феофана ясно, что Папац был наместником хагана» [Чичуров, 1980, с. 179]. Исследователи не видят в этом месте источника противоречия: «Не должно смущать и то обстоятельство, что Никифор называет Папаца архонтом. Под этим термином он, как и другие византийские авторы, понимал не только византийских чиновников, наместников или правителей областей, но и знатных, влиятельных варваров, каким и должен был быть Папац» [Moгаричев и др., 2007, с. 88].

Таким образом, представляется, что Папац - доверенное лицо кагана, «знатный, влиятельный варвар», находившийся при Юстинине с целью устранения последнего по приказу кагана. Архонтом Фанагории Папац не назван ни в одном из источников, но, по всей видимости, он был тудуном, на что может указывать и его «имя»: так же, как Валгиц означает титул правителя baliqci, Bulsici, который может быть связан с праболгарами Прикубанья, Папац может рассматриваться не как имя собственное, а как титул ${ }^{8}$ наместника подконтрольной каганату области на СевероЗападном Кавказе. Территориально, хронологически, а также фонетически с такой областью может быть соотнесена «страна Папагия» в Закубанье.

Насколько жизнеспособной окажется предложенная вниманию читателя версия истории Папагии, покажут будущие исследования. Но уже сегодня она позволяет с иного ракурса взглянуть на решение целого ряда вопросов: о степени вовлеченности племен Северо-Западного Кавказа в «большую политику» великих держав - Византии и Хазарского каганата, о роли Фанагории в военном и административном регулировании жизни населения равнин и предгорий Закубанья, об особенностях взаимоотношений зихов, папагов и касахов, о различном значении этих этнонимов в сменяющих друг друга исторических эпохах. 
И.А. Дружинина. Историческая область Папагия трактата Константина VII Багрянородного

\section{ИЛЛЮСТРАЦИИ}

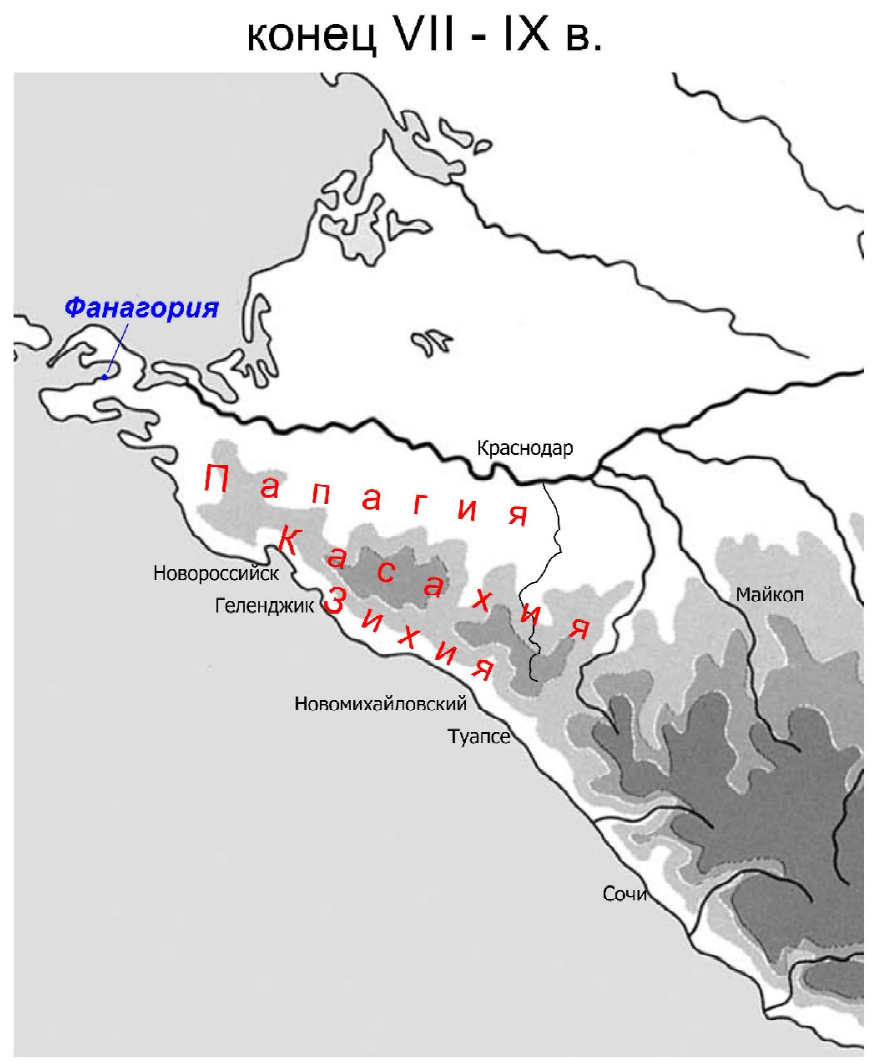

первая половина X в.

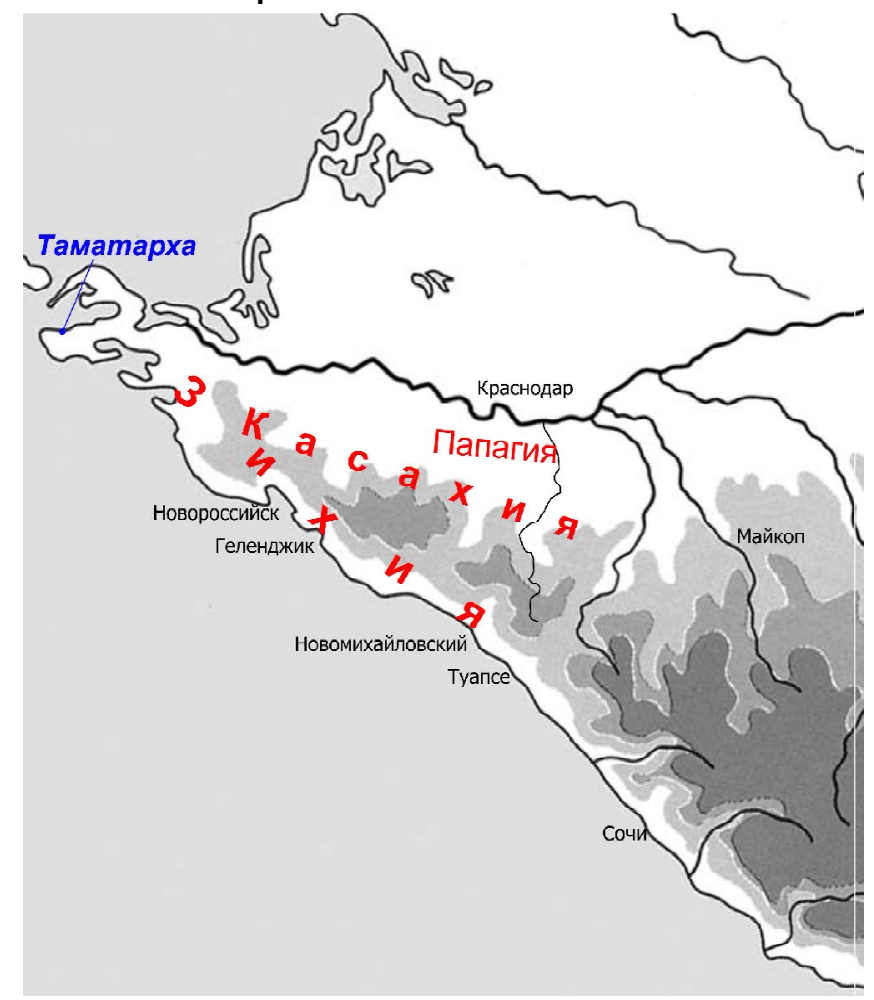

Рис. 1. Локализация Зихии, Папагии и Касахии в конце VII - IX в. и в первой половине X в.

Fig. 1. Localization of Zikhiya, Papagiya and Kasakhiya at the end of the $7^{\text {th }}-$ first half of the $10^{\text {th }} \mathrm{cc}$. 


\section{ПРИМЕЧАНИЯ}

${ }^{1}$ Помимо этого, на могильнике Андреевская щель X-XI вв. под Анапой среди грунтовых кремаций выявлены четыре ингумации [Новичихин, 1993, c. 76]. Однако эти погребения - детские, что, скорее, указывает на восприятие частью местного населения христианства, и лишь косвенно - на переселение зихов, чье появление могло ускорить распространение ингумационного обряда.

${ }^{2}$ Сомнение в праболгарской природе данной группы памятников Закубанья высказала В.Е. Флерова [Флерова, 2002].

${ }^{3}$ При их рассмотрении будем опираться на результаты анализа расположения кремационных могильников хазарского времени, проведенного П.С. Успенским, выделившим три группы этих памятников. В первую группу вошли 10 могильников района Анапы - Геленджика: Дюрсо, Борисовский, Большие Хутора, 8-я Щель, на ул. Днестровской, на г. Болтын, Мысхако, у ст-цы Гостагаевской, Су-Псех и Натухаевская. Вторую группу образуют 7 могильников в степной зоне Западного Закубанья: Ахтырский Лиман, Крюковский мыс, Общественный II, Бугайский Бугор, у хуторов Хабль и Евсеевский, Молдовановский могильник. Третья группа, локализованная в зоне Краснодарского водохранилища, объединяет 5 памятников: Псекупский, Казазово, в устье р. Дыш, Нововочепшийский, Тахтамукайский могильники [Успенский, 2013, с. 90].

${ }^{4} \mathrm{~K}$ концу Х в. ареал кремационных погребений расширяется: они вновь появляются на побережье и распространяются от Новороссийска до Туапсе, впервые могильники с трупосожжениями оказываются в зоне предгорий Западного Закубанья, часть могильников смещается далеко на восток от р. Псекупс, в том числе на территорию Алании, отдельные памятники выявлены в Прикубанье [Пьянков, 2001, с. 205]. Но это уже другой обряд: наблюдается полный переход к урновым кремациям, появляется значительное количество комплексов с конскими захоронениями и новыми типами конского снаряжения, а также оружия и керамики, распространяется практика подкурганных захоронений [Носкова, 2011, с. 106]. В таком виде обряд доживает до XIV в. Представляется вероятным, что после краха Хазарского каганата имя носителей обряда кремаций «растворилось» в историческом этнониме - касоги, ставшем на время обобщающим названием для жителей Западного Закубанья (до появления нового полиэтнонима - черкесы).

${ }^{5}$ При этом важно еще раз подчеркнуть, что население равнинной зоны Закубанья было полиэтничным, на что указывают разнородные археологические памятники, представленные: локальнотерриториальными группами кремационных по- гребений, различающихся по преобладающему способу захоронения останков (урновые, безурновые), трупоположениями в узких ямах с северо-восточной ориентировкой, а также комплексами, демонстрирующими влияние новых обрядов на погребальные традиции местного оседлого населения. Папагия представляется как объединение этнически разнородных групп населения, среди которых господствующее положение занимала элитарная прослойка носителей обряда кремаций.

${ }^{6}$ Согласимся с этим, но с принципиальной поправкой: кашаки Ал-Масуди - это обобщенное название полиэтничного населения Закубанья и части Северо-Восточного Причерноморья первой половины Х в.

${ }^{7}$ Благодарю А.Ю. Виноградова за ценные комментарии к переводу этого места источника.

8 Такую возможность допускал Питер Голден [Golden, 1980, p. 204].

\section{СПИСОК ЛИТЕРАТУРЫ}

Алексеева Е. П., 1971. Древняя и средневековая история Карачаево-Черкесии. М. : Наука. 355 с.

Анфимов Н. В., 1980. Зихские памятники Черноморского побережья Кавказа // Северный Кавказ в древности и средние века. М. : Наука. С. 92-113.

Армарчук Е. А., 2003. Памятники Северо-Восточного Причерноморья X-XIII веков // Крым, Северо-Восточное Причерноморье и Закавказье в эпоху средневековья: IV-XIII века. М. : Наука. С. 207-227.

Артамонов М. И., 1952. Белая Вежа // Советская археология. T. XVI. C. 42-76.

Бубенок О. Б., 2014. Касоги на юго-западной границе Хазарского каганата // Хазарский альманах. Т. 12. Киев ; Харьков. С. 34-68.

Бубенок О. Б., 2015. Сведения письменных источников о западной границе северокавказской Алании в X-XII вв. // Восточная Европа в древности и средневековье. Вып. XXVII. М. : ИВИ PAH. C. 31-36.

Виноградов А. Ю., 2009. Зихия // Православная энциклопедия. Т. 20. М. : Православ. энцикл. С. 186-192.

Гавритухин И. О., Пьянков А. В., 2003. Раннесредневековые древности побережья (IV-IX вв.) // Крым, Северо-Восточное Причерноморье и Закавказье в эпоху средневековья: IVХІІІ века. М. : Наука. С. 186-200.

Гадло А. В., 1979. Этническая история Северного Кавказа IV-Х вв. Л. : Изд-во ЛГУ. 216 с.

Гадло А. В., 1994. Этническая история Северного Кавказа Х-ХІІІ вв. СПб. : Изд-во СПбГУ. 240 с. 
Герасимова М. М., Тихонов А. Г., 2003. Новые краниологические данные к проблеме происхождения адыгов // Горизонты антропологии : тр. Междунар. науч. конф. памяти академика В.П. Алексеева. М. : Наука. С. 286-290.

Джигунова Ф. К., 2000. Западное Предкавказье в IVIX вв. : автореф. дис. ... канд. ист. наук. СПб. $23 \mathrm{c}$.

Джигунова Ф. К., 2007. Социальная и половозрастная градация раннесредневековых погребений на территории Закубанья // Вестник Адыгейского государственного университета. Серия 1, Регионоведение. № 1. С. 154-158.

Дмитриев А. В., 1978. К вопросу об этнической принадлежности трупосожжений конца VIII начала IX века в районе Новороссийска Геленджика // VIII Крупновские чтения. Нальчик : Изд-во КБИ. С. 48-49.

Дружинина И. А., 2016. К изучению этногенеза адыгов по данным краниологии: археологический контекст // XXIX Крупновские чтения. Грозный : Изд-во ЧГУ. С. 211-214.

Дружинина И. А., 2017. Историческая область Папагия трактата Константина VII Багрянородного «Об управлении империей». История изучения // Нижневолжский археологический вестник. Т. 16. № 2. С. 33-49.

Каждан А. П., 1967. [Рец. на кн.:] Constantine Porphyrogenitus. De administrando imperio. Vol. II. A Commentary. Washington (D.C.); Dumbartan Oaks. 221 p. // Византийский временник. T. XXVII. C. 335-337.

Калинина Т. М., 2001. Арабские ученые о нашествии норманнов на Севилью в 844 г. // Древнейшие государства Восточной Европы 1999 г. Восточная и Северная Европа в средневековье. М. : Вост. лит. С. 190-210.

Калинина Т. М., 2015. Проблемы истории Хазарии (по данным восточных источников). М. : Русский фонд содействия образованию и науке. $288 \mathrm{c}$.

Каминский В. Н., 1984. Раннесредневековые аланские катакомбы на Средней Кубани // Вопросы археологии и этнографии Северной Осетии. Орджоникидзе : Кн. тип. ГК СО АССР. С. 11-28.

Каминский В. Н., 1987. Алано-болгарский могильник близ станицы Старокорсунской на Кубани // Советская археология. № 4. С. 187-205.

Каминский В. Н., 1989. Аланы на Северо-Западном Кавказе // Первая Кубанская археологическая конференция. Краснодар : Изд-во КубГУ. С. 96-97.

Каминский В. Н., 1993. Одно из сочинений Константина Багрянородного и этническая карта Северо-Западного Кавказа // Музейный вестник. Вып. 1. Краснодар : Изд-во КГИАМЗ. С. 70-83.
Кочкаров У. Ю., 2006. Комплекс вооружения воинов Северо-Западного Предкавказья в VIIIXIV вв. // XXIV Крупновские чтения : тез. докл. Нальчик : Колорит. С. 119-121.

Кочкаров У. Ю., 2008. Вооружение воинов СевероЗападного Предкавказья VIII-XIV вв. (оружие ближнего боя). М. : Таус. 175 c.

Лавров Л. И., 2009. Адыги в раннем средневековье // Л.И. Лавров. Избранные труды. Нальчик : Изд-во ГП КБР РПК. С. 89-122.

Литаврин Г. Г., 1991. Введение // Константин Багрянородный. Об управлении империей. Текст, перевод, комментарий. М. : Наука. С. 10-30.

Могаричев Ю. М., Сазанов А. В., Шапошников А. К., 2007. Житие Иоанна Готского в контексте истории Крыма «хазарского периода». Симферополь : АнтиквА. 348 с.

Новичихин А. М., 1993. Исследование средневекового могильника Андреевская щель в 1991 и 1992 гг. // Вторая Кубанская археологическая конференция : тез. докл. Краснодар : Изд-во КубГУ. С. 76-77.

Новичихин А. М., 2014. Предметы вооружения, воинского и конского снаряжения из разрушенных погребений могильника Андреевская щель // Военная археология : сб. науч. ст. Вып. 3. М. : МедиаМир; Тула : Куликово поле. C. 55-93.

Носкова Л. М., 2002. К вопросу об этническом составе Закубанья в эпоху раннего средневековья // Материальная культура Востока. Вып. 3. М. : Изд-во ГМВ. С. 169-187.

Носкова Л. М., 2011. Некоторые аспекты этнической истории Среднего Закубанья (по данным погребального обряда) // Диалог городской и степной культур на евразийском пространстве : тез. докл. Казань : Ин-т истории им. Ш. Марджани АНРТ. С. 105-110.

Плетнева С. А., 1981. Древние болгары в бассейне Дона и Приазовья // Плиска-Преслав. 2. Прабългарската култура: Материалы от българо-съветската среща. София : Изд-во на Българската Академия на науките. С. 9-19.

Пьянков А. В., 1989. Проблемы средневековой археологии западных адыгов // Первая Кубанская археологическая конференция. Краснодар : Изд-во КубГУ. С. 111-113.

Пьянков А. В., 1998. Раскопки могильника Бжид-1 на Черноморском побережье Краснодарского края. Предварительные итоги // Древности Кубани. Вып. 8. Краснодар : Изд-во КГИАМЗ. С. 48-54.

Пьянков А. В., 2000. Касоги / касахи / кашаки письменных источников и археологические реалии Северо-Западного Кавказа // IV Минаевские чтения по археологии, этнографии и 
музееведению Северного Кавказа. Ставрополь : Изд-во СтавропГУ. С. 117-120.

Пьянков А. В., 2001. Касоги - касахи - кашаки письменных источников и археологические реалии Северо-Западного Кавказа // Материалы и исследования по археологии Кубани. Вып. 1. Краснодар : Крайбибколлектор. С. 198-213.

Пьянков А. В., 2004. Народ касоги и страна Каса : (К этнополитической ситуации на Северо-Западном Кавказе в VIII-X вв.) // XXIII Крупновские чтения : тез. докл. М. : Изд-во ИА PAH. C. 158-160.

Пьянков А. В., Тарабанов В. А., 2008. Кремационные погребения Кубани и Подонья салтовского времени: опыт сопоставления // Древности юга России : сб. науч. ст. памяти А.Г. Атавина. М. : Изд-во ИА РАН. С. 275-295.

Сорочан С. Б., 2007. Еще раз о тудуне Херсона и статусе Боспора и Фанагории в начале VIII в. // Хазарский альманах. Т. 6. Киев ; Харьков : Международный Соломонов университет. С. 201-222.

Схатум Р. Б., 2002. О некоторых этнических названиях адыгов в прошлом (зихи, касоги, черкесы) // Историко-археологический альманах. Вып. 8. Армавир; М. : Изд-во ИА РАН. С. 154-157.

Тарабанов В. А., 1983. Средневековый могильник у аула Казазово // Историческая этнография: традиции и современность. Вып. ІІ. Л. : Изд-во ЛГУ.С. 148-155.

Тарабанов В. А., 1993. Болгарские племена на территории Края. Хазарский каганат // По страницам истории Кубани. Краснодар : Советская Кубань. С. 35-40.

Тарабанов В. А., 1994. Кремационные погребения VIII-X вв. на территории Краснодарского края и их этническая принадлежность // XVIII Крупновские чтения : тез. докл. Кисловодск : Изд-во СГОКМ. С. 58-59.

Тарабанов В. А., 1996. Средневековье Северо-Западного Кавказа // Очерки истории Кубани. С древнейших времен по 1920 г. Краснодар : Советская Кубань. С. 91-107.

Успенский П. С., 2013. Могильники с трупосожжениями VIII-XIII вв. на Северо-Западном Кавказе (динамика ареала погребального обряда) // Российская археология. № 4. С. 86-98.

Успенский П. С., 2015. Кремационные погребения Северо-Западного Кавказа VIII-XIII вв. как исторический источник : автореф. дис. ... канд. ист. наук. М. 30 с.

Флерова В. Е., 2002. Болгары и археологическое районирование Донских степей // Сучасні проблеми археології. Київ : ІА НАНУ. С. 232-233.

Чичуров И. С., 1980. Византийские исторические сочинения: «Хронография» Феофана, «Бре- виарий» Никифора. Тексты, перевод, комментарий. М. : Наука. 216 с.

Чхаидзе В. Н., 2005а. Бул-ш-ци Песах «Кембриджского документа» и вопрос о локализации Черной Булгарии сочинения Константина Багрянородного и «Повести временных лет» // Проблемы всеобщей истории : сб. науч. ст. Вып. 10. Армавир : Изд-во АГПУ, 2005. С. 170-175.

Чхаидзе В. Н., 2005б. Протоболгары на Таманском полуострове? // VI Боспорские чтения. Боспор Киммерийский и варварский мир в период античности и средневековья. Периоды дестабилизаций, катастроф. Керчь : Изд-во ЦАИ «Деметра». С. 356-361.

Чхаидзе В. Н., 2006а. Погребальные памятники эпохи средневековья с территории Таманского полуострова // XXIV Крупновские чтения : тез. докл. Нальчик : Колорит. С. 196-198.

Чхаидзе В. Н., 2006б. Средневековые погребения в каменных ящиках на Таманском полуострове // Средневековая археология Евразийских степей : сб. науч. ст. : материалы и исследования по археологии Поволжья. Вып. 3. М. ; Йошкар-Ола : Изд-во МарГУ. С. 53-86.

Чхаидзе В. Н., 2007. Гермонасса - Томы - Таматарха: позднеантичный и раннесредневековый город на Боспоре // Археологические вести. № 14. C. 141-144.

Чхаидзе В. Н., 2012а. Фанагория в VI-X веках. М. : Триумф принт. 590 с.

Чхаидзе В. Н., 2012б. К вопросу о присутствии протоболгар на территории Таманского полуострова в конце VI - конце VII в. и о «столице» Великой Булгарии - Фанагории // Дриновський збірник. Т. V. Харків ; Софія : Изд-во ХНУ им. В.Н. Каразина. С. 14-22.

Golden P. B., 1980. An Historico-Philological Inqury into the Origins of the Khazars / Khazar studies. Vol. 1. Budapest : Akadémiai Kiady. 291 p.

MinorskyV., 1960. Balgitzi-"Lord of the Fishes"//Wiener Zeitscrift für die Kunde des Morgenlandes. Band 56. Vienna. P. 130-137.

\section{ИСТОЧНИКИ}

Коковцов П. К., 1932. Еврейско-хазарская переписка в Х в. Л. : Изд-во АН СССР. XXXVIII + 134 c.

Константин Багрянородный, 1991. Об управлении империей / текст, пер., коммент. под ред. Г. Г. Литаврина и А. П. Новосельцева. М. : Наука. 496 с.

Латышев В. В., 1890. Известия древних писателей греческих илатинских оСкифии иКавказе. Т. І. СПб. : Тип. Императорской Академии наук. 948 с.

Минорский В. Ф., 1963. История Ширвана и Дербенда X-XI веков. М. : Вост. лит. 265 с. 
Никифор, 1980. Патриарх Никифор. Бревиарий // Чичуров И.С. Византийские исторические сочинения: «Хронография» Феофана, «Бревиарий» Никифора (тексты, перевод, комментарий). М. : Наука. С. 145-184.

Феофан, 1980. Феофан Исповедник. Хронография // Чичуров И.С. Византийские исторические сочинения: «Хронография» Феофана, «Бревиарий» Никифора (тексты, перевод, комментарий). М. : Наука. С. 17-144.

\section{REFERENCES}

Alekseyeva E.P., 1971. Ancient and medieval history of Karachay-Cherkesia. Moscow, Nauka Publ. 355 p. (in Russian).

Anfimov N.V., 1980. Zygian's monuments of the Black Sea coast of the Caucasus. Severnyi Kavkaz v drevnosti i srednie veka. Moscow, Nauka Publ., pp. 92-113. (in Russian).

Armarchuk E.A., 2003. Monuments of Northeast Black Sea Coast of the X-XIII centuries. Krym, SeveroVostochnoe Prichernomore i Zakavkaze v epokhu srednevekovia: IV-XIII veka. Moscow, Nauka Publ., pp. 207-227. (in Russian).

Artamonov M.I., 1952. Belaia Vezha. Sovetskaja arkheologiya, vol. XVI, pp. 42-76. (in Russian).

Bubenok O.B., 2014. Kasog on southwest border of the Khazar Khaganate. Khazarskii almanakh, vol. 12. Kiev; Kharkov, pp. 34-68. (in Russian).

Bubenok O.B., 2015. Data of written sources on the western border of North Caucasian Alania in the X-XII centuries. Vostochnaia Evropa $v$ drevnosti i srednevekove, iss. XXVII. Moscow, Izd-vo IGH RAS, pp. 31-36. (in Russian).

Vinogradov A.Yu., 2009. Zikhiya. Pravoslavnaia entsiklopediia, vol. 20. Moscow, Pravoslavnaia entsiklopediia Publ., pp. 186-192. (in Russian).

Gavritukhin I.O., Piankov A.V., 2003. Early medieval antiquities of the coast (the IV-IX centuries). Krym, Severo-Vostochnoe Prichernomore $i$ Zakavkaze v epokhu srednevekovia: IVXIII veka. Moscow, Nauka Publ., pp. 186-200. (in Russian).

Gadlo A.V., 1979. Ethnic history of the IV-X centuries of the North Caucasus. Leningrad, Izd-vo LGU. 216 p. (in Russian).

Gadlo A.V., 1994. Ethnic history of the X-XIII centuries of the North Caucasus. Sankt-Peterburg, Izd-vo SPbGU. 240 p. (in Russian).

Gerasimova M.M., Tikhonov A.G., 2003. New craniological data on the problem of the origin of Adygs. Gorizonty antropologii: tr. Mezhdunar. nauch. konf. pamiati akademika V.P. Alekseeva. Moscow, Nauka Publ., pp. 286-290. (in Russian).
Dzhigunova F.K., 2000. Western Caucasus in IVX centuries. Cand. hist. sci. abs. diss. 23 p. (in Russian).

Dzhigunova F.K., 2007. Social and gender-age gradation of early medieval burials in the territory of Zakubanya. Vestnik Adygeiskogo gosudarstvennogo universiteta. Seriia 1, Regionovedenie, no. 1, pp. 154-158. (in Russian).

DmitrievA.V., 1978. To a question of an ethnic origin of cremation of the end of VIII - the beginnings of the IX century near Novorossiysk - Gelendzhik. VIII Krupnovskie chteniia. Nalchik, Izd-vo KBI, pp. 48-49. (in Russian).

Druzhinina I.A., 2016. To the study of the ethnogenesis of the Circassians according craniology: the archaeological context. XXIX Krupnovskie chteniia. Groznyi, Izd-vo ChGU, pp. 211-214. (in Russian).

Druzhinina I.A., 2017. Papagiya of the Constantine VII Porphyrogenitus' Treatise De Administrando Imperio. History of studies. Nizhnevolzhskij arheologicheskij vestnik, vol. 16, no. 2, pp. 33-49.

Kazhdan A.P., 1967. [Rets. na kn.:] Constantine Porphyrogenitus. De administrando imperio. Vol. II. A Commentary. Washington (D.C.); Dumbartan Oaks. 221 p. Vizantiiskii vremennik, vol. XXVII, pp. 335-337. (in Russian).

Kalinina T.M., 2001. Arab scientists about the invasion of the Normans in Seville in 844. Drevnejshie gosudarstva Vostochnoj Evropy 1999 g. Vostochnaja $i$ Severnaja Evropa $v$ srednevekov'e. Moscow, Vostochnaja literatura Publ., pp. 190-210.

Kalinina T.M., 2015. Problems in the history of Khazaria (according to Eastern history). Moscow, Izd-vo Russkii fond sodeistviia obrazovaniiu i nauke. 288 p. (in Russian).

Kaminskii V.N., 1984. Early medieval Alanian catacombs in Central Kuban. Voprosy arkheologii $i$ etnografii Severnoi Osetii. Ordzhonikidze, Izd-vo GK SO ASSR, pp. 11-28. (in Russian).

Kaminskii V.N., 1987. Alano-Bulgarian burial ground near the village of Starokorsunskaya in the Kuban. Sovetskaja arkheologiya, no. 4, pp. 187205. (in Russian).

Kaminskii V.N., 1989. Alans in the North-West Caucasus. Pervaia Kubanskaia arkheologicheskaia konferentsiia. Krasnodar, Izd-vo KubGU, pp. 9697. (in Russian).

Kaminskii V.N., 1993. One of Constantine VII Porphyrogenitus' treatises and ethnic map of the Northwest Caucasus. Muzeinyi vestnik, iss. 1. Krasnodar, Izd-vo KGIAMZ,pp. 70-83. (in Russian).

Kochkarov U.Yu., 2006. The complex weapons of the warriors of the Northwest Caucasus in the VIII- 
XIV centuries. XXIV Krupnovskie chteniia: tez. dokl. Nalchik, Kolorit Publ., pp. 119-121. (in Russian).

Kochkarov U.Yu., 2008. The arms of the soldiers of the Northwest Caucasus in the VIII-XIV centuries (melee weapons). Moscow, Taus Publ. 175 p. (in Russian).

Lavrov L.I., 2009. Adyghe in the early Middle Ages. L.I. Lavrov. Izbrannye trudy. Nalchik, Izd-vo GP KBR RPK, pp. 89-122. (in Russian).

Litavrin G.G., 1991. Introduction. Konstantin Bagrianorodnyi. Ob upravlenii imperiei. Tekst, perevod, kommentarii. Moscow, Nauka Publ., pp. 10-30. (in Russian).

Mogarichev Yu.M., Sazanov A.V., Shaposhnikov A.K., 2007. The life of John of Gothia in the context of the history of the Crimea "Khazar period". Simferopol, AntikvA Publ. 348 p. (in Russian).

Novichikhin A.M., 1993. The study of the medieval burial ground Andreevskaia shchel in 1991 and 1992. Vtoraia Kubanskaia arkheologicheskaia konferentsiia: tez. dokl. Krasnodar, Izd-vo KubGU, pp. 76-77. (in Russian).

Novichikhin A.M., 2014. Weapons, military equipment and harness from the destroyed burials of the burial ground Andreevskaia shchel. Voennaia arkheologiia: sb. nauch. st., iss. 3. Moscow, MediaMir Publ.; Tula, Kulikovo pole Publ., pp. 55-93. (in Russian).

Noskova L.M., 2002. To a question of ethnic structure of Zakubanye during an era of the early Middle Ages. Materialnaia kultura Vostoka, iss. 3. Moscow, Izd-vo GMV, pp. 169-187. (in Russian).

Noskova L.M., 2011. Some aspects of the ethnic history of the Middle Zakuban (according to the funeral rite). Dialog gorodskoj i stepnoj kul'tur na evrazijskom prostranstve: tez. dokl. Kazan', Izd-vo Instituta istorii im. Sh. Mardzhani AN RT, pp. 105-110. (in Russian).

Pletneva S.A., 1981. The ancient Bulgarians in the Don basin and Azov sea. Pliska-Preslav. 2. Prabielgarskata kultura: Materialy ot bielgarosievetskata sreshcha. Sofiia, Izd-vo na Bielgarskata Akademiia na naukite, pp. 9-19. (in Russian).

PiankovA.V., 1989. Problems of medieval archeology of the Western Adyghes. Pervaia Kubanskaia arkheologicheskaia konferentsiia. Krasnodar, Izd-vo KubGU, pp. 111-113.

Piankov A.V., 1998. Excavations burial Bzhid-1 on the Black sea coast of Krasnodar region. Preliminary results. Drevnosti Kubani, iss. 8. Krasnodar, Izd-vo KGIAMZ, pp. 48-54. (in Russian).

Piankov A.V., 2000. Kasog / kasakh / Kashak of written sources and archaeological realities of the Northwest Caucasus. IV Minaevskie chteniia po arkheologii, etnografii $i$ muzeevedeniiu
Severnogo Kavkaza. Stavropol, Izd-vo StavropGU, pp. 117-120. (in Russian).

Piankov A.V., 2001. Kasog - kasakh - kashak of written sources and archaeological realities of the Northwest Caucasus. Materialy $i$ issledovaniia po arkheologii Kubani, iss. 1. Krasnodar, Izd-vo Kraibibkollektor, pp. 198-213. (in Russian).

Piankov A.V., 2004. Kasog and Kasa country (to the ethno-political situation in the North-West Caucasus in VIII-X). XXIII Krupnovskie chteniia: tez. dokl. Moscow, Izd-vo IA RAN, pp. 158-160. (in Russian).

PiankovA.V., Tarabanov V.A., 2008. Cremation burials of the Kuban and the Don of saltov's time: experience mapping. Drevnosti iuga Rossii. Moscow, Izd-vo IA RAN, pp. 275-295. (in Russian).

Sorochan S.B., 2007. Once again on the tudun of Kherson and the status of the Bosporus and Phanagoria in the beginning of VIII century. Khazarskii almanakh, vol. 6. Kiev; Kharkov, Mezhdunarodnyi Solomonov universitet Publ., pp. 201-222. (in Russian).

Skhatum R.B., 2002. Some ethnic Adyg names in the past (Zikhi, Kasogi, Cherkesy). Istorikoarkheologicheskii almanakh, iss. 8. Armavir; Moscow, pp. 154-157. (in Russian).

Tarabanov V.A., 1983. Medieval burial ground at the aul of Kazazovo. Istoricheskaia etnografiia: traditsii i sovremennost, iss. II. Leningrad, Izd-vo LGU, pp. 148-155. (in Russian).

Tarabanov V.A., 1993. Bulgarian tribes in the region. The Khazar khanate. Po stranitsam istorii Kubani. Krasnodar, Sovetskaia Kuban Publ., pp. 35-40. (in Russian).

Tarabanov V.A., 1994. Cremation burials of VIII$\mathrm{X}$ centuries on the territory of Krasnodar region and their ethnicity. XVIII Krupnovskie chteniia: tez. dokl. Kislovodsk, Izd-vo SGOKM, pp. 5859. (in Russian).

Tarabanov V.A., 1996. Middle Ages of the Northwest Caucasus. Studies on history of Kuban. Krasnodar, Sovetskaia Kuban Publ., pp. 91-107. (in Russian).

Uspenskii P.S., 2013. Cemeteries with cremations of the VIII-XIII centuries on the North-Western Caucasus (dynamics of the range of funeral rites). Rossiyskaya arkheologiya, no. 4, pp. 86-98. (in Russian).

Uspenskii P.S., 2015. Cremation burials of the NorthWest Caucasus VIII-XIII centuries as a historical source. Cand. hist. sci. abs. diss. Moscow. 30 p. (in Russian).

Flerova V.E., 2002. Bulgarians and archaeological zoning of the Don steppes. Suchasni problemi arkheologiï. Kiïv, Izd-vo IA NANU, pp. 232233. (in Russian). 
Chichurov I.S., 1980. Byzantine historical works: the Chronicle of Theophanes, "Breviarium» of Nikephoros. Moscow, Nauka Publ. 216 p. (in Russian).

Chkhaidze V.N., 2005a. Bul-sh-tsi Pesakh of «Cambridge Document» and the question of Black Bulgarija' localization in Constantine Porphyrogenitus' treatise and The Russian Primary Chronicle. Problemy vseobshchei istorii: sb. nauch. st., iss. 10. Armavir, Izd-voAGPU, pp. 170-175. (in Russian).

Chkhaidze V.N., 2005b. Protobulgarians on the Taman Peninsula? VI Bosporskie chteniia. Bospor Kimmeriiskii $i$ varvarskii mir v period antichnosti $i$ srednevekovia. Periody destabilizatsii, katastrof. Kerch, Izd-vo TsAI «Demetra», pp. 356361. (in Russian).

Chkhaidze V.N., 2006a. Funeral monuments of the middle ages from the Taman Peninsula. XXIV Krupnovskie chteniia: tez. dokl. Nalchik, Izd-vo Kolorit, pp. 196-198. (in Russian).

Chkhaidze V.N., 2006b. Medieval burials in stone boxes on the Taman Peninsula. Srednevekovaia arkheologiia Evraziiskikh stepei: sb. nauch. st.: materialy $i$ issledovaniia po arkheologii Povolzhia, iss. 3. Moscow; Ioshkar-Ola, Izd-vo MarGU, pp. 53-86. (in Russian).

Chkhaidze V.N., 2007. Germonassa - Tomy Tamatarkha: late antique and early medieval city on the Bosporus. Arkheologicheskie vesti, no. 14, pp. 141-144. (in Russian).

Chkhaidze V.N., 2012a. Phanagoria in VI-X century. Moscow, Triumf print Publ. 590 p. (in Russian).

Chkhaidze V.N., 2012b. On the issue of the protobulgarians presence on the territory of the Taman Peninsula in the late VI - late VII centuries and the "capital" of Great Bulgaria - Phanagoria.
Drinovskii zbirnik, vol. V. Kharkiv; Sofiia, Izdvo KhNU im. V.N. Karazina, pp. 14-22. (in Russian).

Golden P.B., 1980. An Historico-Philological Inqury into the Origins of the Khazars. Khazar studies, vol. 1. Budapest, Akadémiai Kiady Publ. 291 p.

MinorskyV., 1960. Balgitzi-"Lord of the Fishes". Wiener Zeitscrift für die Kunde des Morgenlandes, band 56. Vienna, pp. 130-137.

\section{SOURCES}

Kokovtsov P.K., 1932. Jewish-Khazaria correspondence in the $X$ century. Leningrad, Izd-vo AN SSSR, XXXVIII + 134 p.

Constantine VII Porphyrogenitus, 1991. De Administrando Imperio. Text, translation, commentary. Ed. by G.G. Litavrin and A.P. Novoseltsev. Moscow, Nauka Publ. 496 p.

Latyshev V.V., 1890. Intelligence of ancient writers Greek and Latin about Skifiya and the Caucasus, vol. I, Sankt-Peterburg, Izd-vo Imperatorskaia Akademia nauk. 948 p.

Minorskii V.F., 1963. History of Shirvan and Derbend $X-X I$ centuries. Moscow, Izd-vo Vostochnaia literature. $265 \mathrm{p}$.

Nikifor, 1980. Nikephoros. Breviarium. Chichurov I.S. Vizantiiskie istoricheskie sochineniia: "Khronografiia» Feofana, "Breviarii» Nikifora (teksty, perevod, kommentarii). Moscow, Nauka Publ., pp. 145-184.

Feofan, 1980. Theophanes the Confessor. The Chronicle. Chichurov I.S. Vizantiiskie istoricheskie sochineniia: "Khronografiia» Feofana, «Breviarii» Nikifora (teksty, perevod, kommentarii). Moscow, Nauka Publ.,pp. 17-144.

\section{Information about the Author}

Inga A. Druzhinina, Researcher, Department of Archaeology of the Caucasus, Institute of Archaeology of Russian Academy of Sciences, Dmitriya Ulyanova St., 19, 117036 Moscow, Russian Federation, inga_druzh@mail.ru.

\section{Информация об авторе}

Инга Александровна Дружинина, научный сотрудник Группы археологии Кавказа, Институт археологии РАН, ул. Дм. Ульянова, 19, 117036 г. Москва, Российская Федерация, inga_druzh@mail.ru. 